\title{
ILMU NEGARA SEBAGAI MATA PELAJAR PENGANTAR DI PROGRAM STUDI ILMU HUKUM \\ NOPERIUS HALAWA
}

EMAIL : nopershalawa59@gmail.com

BP:2110003600052

\section{A.Pendahuluan}

Dalam menempuh studi ilmu hukum di Fakultas Hukum, maka mahasiswa selalu dihadapkan oleh mata kuliah-mata kuliah dasar yang menjadi fondasi dalam mempelajari ilmu hukum. Salah satu mata kuliah dasar yang diberikan adalah Ilmu Negara selain mata kuliah dasar lainnya seperti Pengantar ilmu hukum ataupun Pengantar Hukum positif di suatu negara atau yang dahulu disebut Pengantar Tata Hukum dan lain sebagainya. Hal yang menarik adalah bagaimana negara dijadikan salah satu elemen pendukung dalam memahami hukum secara mendasar. Kajian-kajian mendasar mengenai negara yang dibahas didalam mata kuliah Ilmu negara adalah hal-hal yang berkenaan dengan elemen-elemen fundamental dalam negara sebagai objeknya. Oleh karena itu, perlu penjelasan mendasar terhadap konsepsi mengenai negara dan apakah kaitannya dengan hukum, atau secara spesifik mengapa studi ilmu hukum harus didahului dengan mempelajari Ilmu Negara.

Negara merupakan simbol kekuatan suatu komunitas kelompok masyarakat yang telah mengukuhkan untuk bersatu, memiliki arti yang sangat satrategis dalam perannya menyejahterakan masyarakat. Tidak mustahil peran dari negara yang dalam hal ini diarahkan pada sebuah tindakan dari pemerintah acapkali dimintai pertanggungjawaban atas semua tindakan yang dibuatnya. Mulai dari terbentuknya sebuah negara, adanya kemurnian ajaran untuk berorientasi pada sebuah pandangan yang jauh ke depan yaitu paham kesejahteraan harus ditanamkan sedemikian rupa. Adanya pandangan jauh ke depan tersebut bukan berarti mengesampingkan kepentingan saat ini, akan tetapi jauh kedepan berarti keyakinan akan suatu bentuk prospek yang lebih baik dari masa-masa sebelumnya. 
Persoalan yang kemudian mengemuka dalam negara adalah ihwal praktik eksistensi dari sebuah legitimasi. Ketentuan formalitas dalam pembentukan negara tidak selalu menghadirkan bentuk negara yang dapat dikatakan layak dalam proses pendiriannya. Namun untuk masa saat ini adanya legitimasi yang kuat menjadi bentuk lain dari sebuah kekuatan negara yang dapat dikatakan ideal. Sehingga diperlukan pemahaman mengenai negara yang berdasarkan hukum agar dapat kembali berdiri sesuai mandat supremasinya yakni dengan kembali menggali pemahaman radikal dan mendasar tentang negara dengan konstruksi ideal negara hukum

Ilmu Negara merupakan mata kuliah wajib di dalam kurikulum inti Fakultas Hukum di Indonesia, yang menjadi ilmu pengetahuan dasar mengenai negara dan hukum yang akan didalami lebih lanjut dalam mata kuliah pada cabang-cabang ilmu hukum, terutama Hukum Tata Negara; Hukum Administrasi Negara dan Hukum Internasional. Karena itu, bahasan dalam mata kuliah ini meliputi aspek-aspek keilmuan Ilmu Negara; kualifikasi, hakikat, tujuan dan fungsi negara; teori-teori kekuasaan dan ajaran kedaulatan; timbul dan lenyapnya negara; tipe-tipe Negara; bentuk negara dan pemerintahan; serta susunan dan hubungan antar-negara.

Mata kuliah Ilmu Negara ini berusaha sejauh mungkin untuk mengkorelasikan teori-teori mengenai negara dan hukum dengan realita melalui berbagai contoh yang diberikan dalam perkuliahan terutama didiskusikan dalam kegiatan tutorial. Dengan demikian, diharapkan mahasiswa mampu memahami aspek-aspek keilmuan dari Ilmu Negara; kualifikasi, hakikat, tujuan dan fungsi negara; teori-teori kekuasaan dan ajaran kedaulatan; timbul dan lenyapnya negara; tipe-tipe Negara; bentuk negara dan pemerintahan; serta susunan dan hubungan antar-negara.

Dengan demikian, mahasiswa mampu menjelaskan mengenai terminologi dan pengertian Ilmu Negara, kedudukan Ilmu Negara dalam kurikulum dan sistematika ilmu hukum, obyek 
dan runglingkup Ilmu Negara, metode dalam Ilmu Negara,serta hubungan Ilmu Negara dengan ilmu-ilmu kenegaraan lain; istilah dan pengertian negara, hakikat negara, unsurunsur dan ciri-ciri negara tujuan dan fungsi negara. Mahasiswa mampu menguraikan mengenai kekuasaan dan kewibawaan, legitimasi kekuasaan, dan teori kedaulatan; teori timbulnya negara, teori lenyapnya negara. Mahasiswa mampu menguraikan dan memberikan contoh tipetipe negara berdasarkan sejarah dan tipe-tipe negara berdasarkan hukum/hubungan pemerintah dan rakyat; pengertian bentuk negara dan pemerintahan, teori-teori bentuk negara, teori-teori bentuk pemerintahan; susunan negara, hubungan antarnegara 


\section{B. PEMBAHASAN}

Seorang sarjana bernama George Jellinek, dalam bukunya yang berjudul Algemeine

Staatslehre mengungkapkan Ilmu Negara mempunyai sistematika sebagai berikut:

1) Ilmu Negara sebagai ilmu pengetahuan dalam arti yang sempit

(Staatswissenschaft), yang menyelidiki negara dalam keadaan abstrak dan umum.

2) Ilmu Negara sebagai ilmu pengetahuan dalam arti luas (Rechtswissenschaft), yang terbagi ke dalam 2 kategori yaitu:

a. Ilmu pengetahuan yang yang menyelidiki negara tertentu, misalnya mempelajari lembaga negara, peradilan, dan sebagainya (Individuelle Staaslehre); dan

b. Ilmu pengetahuan yang penyelidikannya ditujukan kepada negara dalam pengertian umum serta lembagalembaga perwakilan yang dipelajari secara khusus (Pezielle Staaslehre).

George Jellinek, merupakan sosok yang pertama sekali merumuskan Ilmu Negara sebagai suatu ilmu pengetahuan yang berdiri sendiri. Karena itu, ia kerap kali diberi julukan “Bapak Ilmu Negara.” Hal ini menimbulkan pertanyaan, yaitu apakah sebelum sistematisasi oleh George Jellinek itu Ilmu Negara telah dipelajari sebagai ilmu pengetahuan? Dalam hal ini masih menimbulkan spekulasi, sebab pada waktu sebelumnya, Ilmu Negara belum merupakan suatu ilmu pengetahuan yang mandiri dan sifatnya masih deskriptif atau mencakup segala pengetahuan yang berhubungan dengan negara. Persoalan seperti agama, politik, kebudayaan, moral, dan ekonomi yang berhubungan dengan negara dimasukkan ke dalam pembicaraan Ilmu Negara. 
Hal tersebut dapat diketahui dari karya Plato dan Aristoteles pada masa Yunani Kuno dalam buku yang berjudul Politeia dan Politica yang membicarakan persoalan-persoalan negara di dalamnya. Pada masa itu, objek yang diamati dan dipelajari adalah negara kota (city state) yang dikenal dengan istilah polis dengan wilayah yang tidak seberapa luas dan jumlah penduduk yang tidak banyak. Sehingga tidak mengherankan jika semua ihwal persoalan yang berhubungan dengan negara dapat disusun dan dituangkan dalam suatu karya yang membahas mengenai negara. Tetapi kondisi itu dalam perkembangan waktu tidak dapat dipertahankan lagi dengan kemunculan negara bangsa (nation state) dengan batasbatas kedaulatan yang semakin lama semakin luas dengan jangkauan wilayah dan penduduk yang lebih besar lagi. Akibat kondisi ini, maka dibutukan pelajaran mengenai negara yang perlu disistematisasi dalam ilmu pengetahuan yang mandiri.

Perkembangan Ilmu Negara di Indonesia, pertama kali diperkenalkan oleh Universitas Gadjah Mada, saat merintis sebagai perguruan tinggi swasta (1946). Pada saat menyusun materi pelajaran untuk Fakultas Hukum, Universitas Gadjah Mada membandingkan dengan Rechstsschool di Jakarta pada masa Hindia Belanda. Akan tetapi struktur kurikulum ternyata dianggap tidak sesuai dengan kenyataan alam kemerdekaan dan kemudian dicarikan pembanding di Universitas Leiden, Belanda. Sehubungan dengan itu, kuliah awal Ilmu Negara diberi titel Staasleer yang mencakup hal-hal pokok mengenai sendi-sendi negara dan lepas dari kenyataan kolonial. Dalam perkembangannya, ada juga yang menggunakan istilah Teori Negara, terutama dalam kajian Ilmu Politik, untuk mensistematisasikan objek penyelidikan mengenai negara tersebut.

Di dalam kepustakaan dijumpai beberapa istilah yang konotatif pada pengertian Ilmu Negara. Hal itu terdapat di kawasan Eropa Kontinental, Anglo Saxon, maupun di Indonesia. 
Pemahaman atas peristilahan tersebut dapat dilakukan secara etimologi maupun secara gramatika. Di Indonesia istilah Ilmu Negara pertama kali digunakan oleh Universitas Gajah Mada, Yogyakarta tahun 1946. Selain istilah Ilmu Negara, terdapat pula istilahistilah lain untuk sebutan ilmu pengetahuan mengenai negara, seperti: Ilmu Kenegaraan, Teori Negara, Ajaran Negara, dan Ilmu Politik. Ilmu Negara merupakan mata kuliah wajib yang termasuk dalam kurikulum inti. Karena itu, Ilmu Negara sebagai salah satu mata kuliah yang memberikan kompetensi keilmuan, sebagai kompetensi utama bagi mahasiswa. Ilmu Negara mejadikan negara sebagai bidang kajiannya.

Roelolf Kranenburg dalam bukunya Algemene Staatsleer mengemukakan bahwa negara merupakan bidang penyelidikan Ilmu Negara, yang mencoba menyelidiki mengenai asal mulanya, sifat hakikatnya, dan bentukbentuknya. Hal ini sejalan dengan pandangan M.Nasroen yang menyatakan bahwa ”... sebab wujud dari Ilmu Negara Umum ialah menyelidiki dan menetapkan asal mula, sari dan wujud negara itu pada umumnya." Ilmu Negara memiliki cara kerja untuk mendapatkan pengetahuan mengenai negara yakni melalui metode ilmiah. Selain itu, Ilmu Negara juga menggunakan metode ilmiah yang dimiliki oleh ilmu yang lain (pendekatan - approach) dalam mengkaji obyeknya. Di Eropa Kontinental terdapat perbedaan metode dalam Ilmu Negara menurut G. Jellinek, Hans Kelsen, dan R. Kranenburg.

Sedangkan di Anglo Saxon terdapat dua metode dalam Ilmu Negara yang digunakan oleh MacIver dalam bukunya Web of Government. Di Indonesia, metode dalam Ilmu Negara secara khusus dibahas oleh Sjachran Basah dalam bukunya "Ilmu Negara (Pengantar, Metode, dan Sejarah Perkembangan)". Djokosutono dalam bukunya "Ilmu Negara" menyinggung mengenai metode dalam kaitannya dengan pembahasan atas 
pendapat

G. Jellinek,

MacIver,

dan

Hans

Kelsen.

Definisi Negara yang pada prinsipnya bersifat dinamis bertolak belakang dengan pengertian ilmu Negara yang bersifat statis. Ilmu Negara lebih cenderung di artikan sebagai ilmu pengetahuan yang menyelidiki asas-asas pokok, pengertian-pengertian pokok dan masalah-masalah yang berhubungan dengan negara. Disini yang perlu digaris bawahi dalam pengertian ilmu negara adalah pada posisi pengertian ilmu pengetahuan sebagai landasan dari ilmu Negara. Pengertian ilmu Negara adalah hasil pemikiran manusia yang obyektif yang disusun secara sistematis. Suatu pengetahuan semata-mata belum merupakan suatu ilmiah oleh karena syarat pertama yaitu syarat obyektif, oleh karena ilmu pengetahuan mengejar kebenaran yang diterima umum. Syarat kedua adalah syarat sistematis oleh karena hubungan antar pengertian yang diperolehnya tidak boleh bercerai-berai melainkan satu kesatuan yang erat (Moh Kusnardi dan Bintan R. Saragih, 1985;7).

Pengaruh dari perubahan definisi negara tidak akan berpengaruh terhadap pengertian dari ilmu Negara karena sifat dari ilmu dalam kajian Negara bersifat obyektif dan sistematis. Sifat obyektif dan sistematis tersebut menjadikan ilmu negara memiliki definisi yang tidak dapat berubah-ubah dan selalu dapat menyesuaikan dengan kondisi.

Ilmu Negara telah lama diajarkan, namun baru pada permulaan abad ke-20 disusun sebagai suatu ilmu pengetahuan secara sistematis oleh George Jellinek. Dengan adanya perkembangan situasi masyarakat seperti yang diajarkan oleh Herbert Spencer 4 , maka dibutuhkan cabang-cabang ilmu pengetahuan yang mengadakan penyelidikan khusus mengenai bidang- bidang tertentu. Dengan adanya kenyataan itu maka Ilmu Negara kemudian mempunyai relasi dengan cabang-cabang ilmu pengetahuan yang lain, yang antara 
lain dengan ilmu Hukum Tata Negara, Ilmu Hukum Administrasi Negara, Ilmu Politik, dan IlmuEkonomi.

\section{Hubungan Ilmu Negara dengan Ilmu Hukum Tata Negara}

Telah dikemukakan bahwa Ilmu Negara mempunyai objek penyelidikan bersifat umum mengenai pertumbuhan, wujud, formasi, dan lenyapnya negara atau dapat pula mengenai negara tertentu. Inilah kesamaan Ilmu Negara dengan Ilmu Hukum Tata Negara, yaitu sama-sama mempunyai objek penyelidikan berupa negara. Akan tetapi, dalam Ilmu Hukum Tata Negara, objek penyelidikan itu lebih konkrit, karena terikat dengan waktu, tempat, keadaan, dan tata pengaturan tertentu, misalnya Hukum Tata Negara Indonesia, Hukum Tata Negara Amerika Serikat, dan sebagainya. Bahkan, ada yang mengatakan dengan tegas bahwa Ilmu Hukum Tata Negara adalah hukum mengenai organisasi negara.

Oleh sebab itu, rincian pembahasan dalam Ilmu Hukum Tata Negara dikaitkan dengan organ-organ negara, hubungan antarorgan negara, kewaganegaraan, keabsahan undang-undang, dan sebagainya. Dengan demikian, keterikatan antara kedua cabang ilmu pengetahuan itu adalah kesamaan dalam objek akan tetapi persoalan-persoalan yang dibahas berlainan. Sudah barang tentu, untuk mempelajari Ilmu Hukum Tata Negara harus mempunyai bekal pengantar yang cukup mengenai pokok- pokok hal yang berkaitan dengan sendi-sendi negara yang semuanya terdapat dalam Ilmu Negara.

2. Hubungan Ilmu Negara dengan Ilmu Hukum Adminsitrasi Negara

Secara umum, hukum adminsitrasi didefinisikan sebagai hukum yang mengatur hubungan antara organ administrasi dengan warga masyarakat. Bidang-bidang yang menjadi fokus pembahasan adalah perizinan, pegawai negeri, pajak, pendaftaran yang menciptakan hak, dan sebagainya. Dengan demikian, yang dipelajari Ilmu Hukum 
Administrasi Negara sama dengan Ilmu Negara yaitu negara. Hanya perbedaannya, apabila Ilmu Negara menyelidiki sendi-sendi pokok Negara secara umum dan abstrak. Sebaliknya, Ilmu Hukum Administrasi Negara justru mengkaji “negara dalam keadaan bergerak", yaitu hubungan antara (organ) negara dengan masyarakat." Oleh sebab itu, Ilmu Negara menjadi dasar dalam mempelajari Ilmu Hukum Administrasi Negara, karena untuk mempelajari ilmu terakhir itu membutuhkan juga pengertian- pengertian pokok yang berkaitan dengan negara

\section{C.PENUTUP}

Ilmu Negara merupakan mata kuliah wajib yang termasuk dalam kurikulum inti. Karena itu, Ilmu Negara sebagai salah satu mata kuliah yang memberikan kompetensi keilmuan, sebagai kompetensi utama bagi mahasiswa. Ilmu Negara mejadikan negara sebagai bidang kajiannya.Ilmu Negara merupakan mata kuliah wajib di dalam kurikulum inti Fakultas Hukum di Indonesia, yang menjadi ilmu pengetahuan dasar mengenai negara dan hukum yang akan didalami lebih lanjut dalam mata kuliah pada cabang-cabang ilmu hukum, terutama Hukum Tata Negara; Hukum Administrasi Negara dan Hukum Internasional. Karena itu, bahasan dalam mata kuliah ini meliputi aspek-aspek keilmuan Ilmu Negara; kualifikasi, hakikat, tujuan dan fungsi negara; teori-teori kekuasaan dan ajaran kedaulatan; timbul dan lenyapnya negara; tipe-tipe Negara; bentuk negara dan pemerintahan; serta susunan dan hubungan antar-negara. 


\section{DAFTAR PUSTAKA}

Darmini Roza dan Laurensius Arliman S, Peran Pemerintah Daerah Di Dalam Melindungi Hak Anak Di Indonesia, Masalah-Masalah Hukum, Volume 47, Nomor 1, 2018. https://doi.org/10.14710/mmh.47.1.2018.10-21 Laurensius Arliman S, Peranan Metodologi Penelitian Hukum di Dalam Perkembangan Ilmu Hukum di Indonesia, Soumatera Law Review, Volume 1, Nomor 1, 201. http://doi.org/10.22216/soumlaw.v1i1.3346. Laurensius Arliman S, Peran Badan Permusyawaratan Desa di Dalam Pembangunan Desa dan Pengawasan Keuangan Desa, Padjadjaran Journal of Law, Volume 4, Nomor 3, 2017. https://doi.org/10.15408/jch.v4i2.3433. Laurensius Arliman S, Penanaman Modal Asing Di Sumatera Barat Berdasarkan Undang Undang Nomor 25 Tahun 2007 Tentang Penanaman Modal, Supremasi Hukum, Volume 1, Nomor 1, 2018.

http://dx.doi.org/10.36441/hukum.v1i01.102 . Laurensius Arliman S, Memperkuat Kearifan Lokal Untuk Menangkal Intoleransi Umat Beragama Di Indonesia, Ensiklopedia of Journal, Volume 1, Nomor 1, 2018, https://doi.org/10.33559/eoj.v1i1.18. Laurensius Arliman S, Perkawinan Antar Negara Di Indonesia Berdasarkan Hukum Perdata Internasional, Kertha Patrika, Volume 39, Nomor 3, 2017, https://doi.org/10.24843/KP.2017.v39.i03.p03.

Laurensius Arliman S, Partisipasi Masyarakat Di Dalam Pengelolaan Uang Desa PascaUndang Undang Nomor 6 Tahun 2014 Tentang Desa, Jurnal Arena Hukum, Volume 12, Nomor 2, 2019, https://doi.org/10.21776/ub.arenahukum.2019.01202.5. Laurensius Arliman S, Mewujudkan Penegakan Hukum Yang Baik Di Negara Hukum Indonesia, Dialogica Jurnalica, Volume 11, Nomor 1, 2019, https://doi.org/10.28932/di.v11i1.1831. Laurensius Arliman S, Mediasi Melalui Pendekatan Mufakat Sebagai Lembaga Alternatif Penyelesaian Sengketa Untuk Mendukung Pembangunan Ekonomi Nasional, UIR Law Review, Volume 2, Nomor 2, 2018, https://doi.org/10.25299/uirlrev.2018.vol2(02).1587 Laurensius Arliman S, Peranan Filsafat Hukum Dalam Perlindungan Hak Anak Yang 
Berkelanjutan Sebagai Bagian Dari Hak Asasi Manusia, Doctrinal, Volume 1, Nomor 2,2016. Laurensius Arliman S, Ni Putu Eka Dewi, Protection of Children and Women's Rights in Indonesiathrough International Regulation Ratification, Journal of Innovation, Creativity and Change Volume 15, Nomor 6, 2021. Laurensius Arliman S, Gagalnya Perlindungan Anak Sebagai Salah Satu Bagian Dari Hak Asasi Manusia Oleh Orang Tua Ditinjau Dari Mazhab Utilitarianisme, Jurnal Yuridis, Volume 3, Nomor 2, 2016, http://dx.doi.org/10.35586/.v3i2.180. Laurensius Arliman S, Tantangan Pendidikan Kewarganegaraan Pada Revolusi 4.0, Jurnal Ensiklopedia Sosial Review, Volume 2, Nomor 3, 2020 . 